\title{
STRATEGIC MAP AS A PART OF RESEARCH WORK OF STUDENTS OF HIGHER EDUCATIONAL INSTITUTIONS
}

\section{СТРАТЕГІЧНА КАРТА ЯК ЧАСТИНА НАУКОВО-ДОСЛІДНИЦЬКОЇ РОБОТИ СТУДЕНТІВ ВИЩИХ НАВЧАЛЬНИХ ЗАКЛАДІВ}

\author{
Yuliia V. Derkachenko \\ derkachenko76@gmail.com \\ ORCID: 0000-0002-3019-9730 \\ Tatiana V. Baulina \\ tanyabaulina@gmail.com \\ ORCID: 0000-0002-0110-849X \\ Tamara V. Kuchtyk \\ ditmtvk@icloud.com \\ ORCID: 0000-0002-2000-3669
}

\author{
Ю. В. Деркаченко, \\ канд. юрид. наук
}

Т. В. Бауліна,

докт. екон. наук, проф.

\section{Т. В. Кухтик,}

докт. техн. наук, проф., ректор

\section{Donbass Institute of Technology and Management of Academician Yuriy Bugay International Scientific and Technical University, Kramatorsk \\ Донбаський інститут техніки та менеджменту Міжнародного науково-технічного університету імені академіка Юрія Бугая, м. Краматорськ}

\begin{abstract}
The goal of the article is development and justification of theoretical and methodological principles, methodological foundations and practical recommendations on the devoted to the study of the essence of strategic maps and the possibility of using the basics of strategic management in the educational process of students of higher educational institutions in the field of "Computer Science". Strategic maps are a simple and clear way to build a line of research work with a clear plan of action, a description of the expected results. They streamline the student's activities, make it more effective, allow to achieve higher results. The article raises the issue of using the basics of strategic management in the educational work of university students for the first time and presents the experience of the Donbas Institute of Technology and Management of Higher Education "International Scientific and Technical University named after Academician Yuri Bugay". The strategic map is a cause-and-effect diagram, which provides the student's movement from choosing a research topic, selecting and processing literature to writing sections, introductions and conclusions, creating applications. It includes not only the required stages of work, but also the expected results. The supervisor helps to create a strategic map and then monitors the student's movement from one stage of work to another. The finished master's thesis is subject to defence and completes the student's research work. This problem is relevant, because in the face of rapid change in various spheres of life, a person must plan their time, allocate it and use it effectively.

It is investigated that a strategic map is a way to reflect the student's strategy, goals and directions of his search activities. For students in Computer Science, these are cause-and-effect diagrams. The first step of a student in writing a master's degree is to compile such a diagram. It should include all stages of the search and the expected results.

Key words: higher school; strategic management; strategic map; research work; master's thesis.
\end{abstract}

Анотація. Мета - розробка й обгрунтування теоретико-методологічних засад, методичних основ та практичних рекомендацій щодо вивчення сутності стратегічних карт та можливості використання основ стратегічного менеджменту в навчальному процесі студентів вищих навчальних закладів напряму «Комп'ютерні науки». Стратегічні карти є простим та наочним способом побудови лінії науково-дослідної роботи з чітким планом дій, описом очікуваних результатів. Вони упорядковують діяльність студента, роблять ії більш ефективною, дозволяють досягати більш високих результатів. Стаття вперше порушує питання використання основ стратегічного менеджменту в навчальній роботі студентів ВНЗ та представляє досвід Донбаського інституту техніки та менеджменту вищого закладу освіти «Міжнародний науково-технічний університет імені академіка Юрія Бугая». Стратегічна карта являє собою причинно-наслідкову діаграму, яка передбачає рух студента від вибору теми дослідження, підбирання та опрацювання літератури до написання розділів, вступу та висновків, створення додатків. Вона включає не тільки обов'язкові етапи роботи, але і прописані очікувані результати. Науковий 
керівник допомагає створити стратегічну карту, а потім контролює рух студента від одного етапу роботи до іншого. Готова магістерська робота підлягає захисту та завершує науково-дослідну роботу студента. Поставлена проблема є актуальною, оскільки в умовах швидких змін у різних сферах життя людина повинна планувати свій час, розподіляти його та ефективно використовувати.

Досліджено, що стратегічна карта - це спосіб відбиття стратегії студента, цілей та напрямів його пошукової діяльності. Для студентів напряму «Комп’ютерні науки» це причинно-наслідкові діаграми. Першим кроком студента під час написання магістерської роботи є саме складання такої діаграми. Вона має включати всі етапи пошукової роботи та очікувані результати.

Ключові слова: вища школа; стратегічний менеджмент; стратегічна карта; науково-дослідна робота; магістерська робота.

\section{ПОСТАНОВКА ЗАДАЧІ}

У сучасному світі відбуваються глибокі та якісні зміни в усіх сферах життя, що пов’язані з інтеграційними процесами, поширенням та вдосконаленням інформаційнокомп’ютерних технологій, автоматизацією, оцифровкою даних та діджиталізацією. Отже, спеціаліст XXI століття має відповідати багатьом вимогам, щоб успішно будувати кар'єру та досягати професійних висот, бути конкурентоспроможним. Протягом життя йому слід удосконалювати старі та набувати нові навички, постійно вчитись. На цьому шляху важливу роль відіграють дисциплінованість, організованість, відповідальність, уміння планувати та розподіляти час. Ці якості мають бути сформовані вже під час отримання вищої освіти, щоб і процес навчання дав найкращий результат. Правильна організація такого навчання, створення власної стратегії набування знань, умінь та навичок, формування важливих компетентностей і $є$ першим завданням сучасного студента, який планує будувати успішну кар'єру, рухатись кар'єрними сходами. Завданням викладачів є допомога у побудуванні такої стратегії та виконанні навчального плану відповідно до індивідуальних та психологічних особливостей студента. Отримати максимальний результат за витрачання мінімуму енергії - важлива умова будь-якої діяльності у сучасному світі, в якому все змінюється дуже швидко. Отже, слід правильно планувати та організовувати діяльність, у тому числі і навчальну.

Під час вивчення великого обсягу інформації слід уміти з нею працювати, систематизувати та класифікувати іiі. Студенти у разі підготовки магістерських робіт часто стикаються з проблемою аналізу масиву підручників, статей, монографій з вибраної тематики, побудови та реалізації плану роботи. Їм допоможуть знання основ стратегічного менеджменту. Для полегшення написання магістерських робіт у Донбаському інституті техніки та менеджменту ВЗО «Міжнародний науковотехнічний університет імені академіка Юрія Бугая» студентам різних спеціальностей пропонується спочатку скласти стратегічну карту магістерської роботи, щоб систематизувати та впорядкувати роботу над нею.

\section{АНАЛІЗ ОСТАННІХ ДОСЛІДЖЕНЬ І ПУБЛІКАЦІЙ}

Наукові статті присвячені складанню стратегічних карт щодо розвитку підприємств та роботи пер- соналу [1-6]. У нашій же статті вперше пропонується використати стратегічні карти в навчальному процесі студентів вищих навчальних закладів 3 метою впорядкування та вдосконалення їхньої навчальної та пошукової діяльності.

\section{ВІДОКРЕМЛЕННЯ НЕ ВИРІШЕНИХ}

\section{РАНІШЕ ЧАСТИН ЗАГАЛЬНОЇ ПРОБЛЕМИ}

Проведений аналіз вітчизняного досвіду підготовки фахівців економічного профілю показав, що ефективному формуванню проєктувальних умінь 3 розробки стратегічних карт сприяє використання комп'ютерних технологій.

\section{МЕТА ДОСЛІДЖЕННЯ}

Головна мета статті - проаналізувати досвід застосування стратегічних карт під час написання студентами старших курсів магістерських робіт.

\section{МЕТОДИ, ОБ'СКТ ТА ПРЕДМЕТ ДОСЛІДЖЕННЯ}

Серед використаних методів дослідження слід підкреслити аналіз, порівняльний метод, метод систематизації. Об'єктом дослідження є впровадження у науково-дослідницьку діяльність студентів основ стратегічного менеджменту, а предметом - вивчення структури та особливостей стратегічних карт та їх використання в процесі написання магістерських робіт.

\section{ОСНОВНИЙ МАТЕРІАЛ}

32013 року активно обговорювалась у літератуpi проблема побудови стратегічних карт для підприємств [1-6]. У такі карти включались цілі, завдання та всі процеси, які були збалансовані вертикально та горизонтально. Всі дії на підприємстві були наглядно взаємопов'язані, мали індикатори, які демонстрували і шляхи здійснення плану, і темпи досягнення цілей. Стратегічна карта - це простий та наочний спосіб відбиття стратегії підприємства, їі цілей і напрямів розвитку. Їх поширювали серед працівників, щоб перенести стратегію на операційний рівень діяльності [1]. У США така методика розвитку підприємства називається роудмепінг, рух по дорожній карті. Він передбачає побудову дорожніх мап, тобто маршрутів розвитку компанії в майбутньому за основними сферами діяльності, зокрема такими як ринок, продукти, 


\section{КОМП'ЮТЕРНІ НАУКИ ТА ІНФОРМАЦІЙНІ ТЕХНОЛОГІЇ №3-2020}

технології, конкуренти, сировина тощо. При цьому основною його домінантою $є$ саме впровадження інновацій, інноваційних технологій [2]. Узгоджені набори візуальних звичаїв, правил під час складання таких мап відсутні. Однією з найбільших вигід такого методу є комунікація через функціональні та організаційні кордони. Процес розробки стратегічних карт об'єднує разом та узгоджує різні ключові зацікавлені сторони та перспективи [2].

Карти можуть мати різний вигляд (причиннонаслідкові діаграми, процесні моделі, матриці, павутинні діаграми). Вони є унікальними, оскільки стратегія кожної організації $є$ унікальною, однак дають відповіді на два головні питання: як досягти успіху та як його оцінити [7]. Стратегічні карти дозволяють перейти від розробки стратегії до iï реалізації та дають інструментарій контролю виконання планів, роблять структуру стратегічного управління «бачення - стратегія - процеси - показники - рішення» завершеною і служать підставою для своєчасного прийняття і коригування стратегічних рішень, прийнятих організацією [7].

До алгоритму формування стратегічної карти входять:

1. Формування генеральних цілей та основних напрямів розвитку.

2. Формування стратегічних цілей, які забезпечують реалізацію генеральних цілей.

3. Визначення локальних цілей для кожного напряму.

4. Встановлення взаємозв'язків між локальними цілями одного напряму.

5. Встановлення взаємозв'язків між локальними цілями різних напрямів.

6. У межах локальних цілей формування оцінювальних показників для відстеження рівня досягнення поставлених цілей.

7. Відповідно до взаємозв'язків локальних цілей встановлення зв'язків між оцінювальними показниками [5, с. 224-225].

Також дослідники пропонували складати стратегічні карти для більш ефективного управління людським капіталом. Такі карти включали стратегію розвитку, імідж компанії та iï цінності, шляхи вдосконалення процесів, особливості функціонування, заплановані результати [4, с. 230]. Їхня місія полягає у стимулюванні працівників на досягнення цілей компанії [4, с. 232]. Людський капітал у таких стратегічних картах представлений за допомогою нефінансових показників (компетентність, умотивованість, ступінь задоволеності результатами роботи). Подібні карти дають змогу аналізувати та оцінювати результати роботи підприємства за певний період, а також ефективно управляти своєю діяльністю на основі такого аналізу, шукати нові підходи до керування персоналом [4, с. 231]. Дослідники пропонують використовувати від 10 до 20 показників на корпо- ративному рівні, від 5 до 10 - на рівні відділів, від 3 до 5 - на рівні конкретних працівників. Це повинні бути лише ті показники, на динаміку яких працівники можуть впливати; кожен з них повинен мати прогнозне (цільове) значення. Впровадження стратегічної карти реалізується через складання плану конкретних дій [4, с. 231]. Переглядатись вони мають щороку, виконуючи контрольну та оціночну функції загалом та стосовно конкретних працівників [4, с. 233-234]. Карта складається шляхом моделювання 3 використанням інформаційно-комп'ютерних технологій [7].

Стратегічна карта є ефективним інструментом управління діяльністю підприємства, іiї успішна реалізація залежить від професіоналізму працівників.

Використання стратегічних карт у процесі навчання допоможе студентам систематизувати, упорядкувати свою науково-дослідну роботу, рухатись за чітким планом, поетапно, вдосконалюючи навички роботи з інформацією.

Студенти, які навчаються за напрямом «Комп'ютерні науки», повинні мати власну стратегічну карту для полегшення виконання усіх цілей та завдань магістерської роботи. План роботи передбачає рух від отримання завдання до захисту результатів пошукової роботи. Вибравши тему дослідження, студент створює джерельну базу, працює з підручниками, науковими журналами, Інтернет-ресурсами. Після підбирання та детального опрацювання літератури студенти працюють над структурою роботи, яка включає вступ, декілька розділів, висновки, додатки. Стратегічна карта для написання наукової роботи 3 комп’ютерних наук може мати такий вигляд (рис. 1).

Науковий керівник має допомогти студенту у складанні індивідуальної стратегічної карти, контролювати виконання усіх етапів роботи.

У вступі магістерської роботи студенти подають:

- мету і завдання роботи;

- актуальність та науково-практичне значення вибраної теми;

- об'єкт та предмет дослідження;

- обгрунтування необхідності нової розробки або удосконалення (модернізації) наявного об'єкта дослідження на основі аналізу сучасного стану проблеми за даними вітчизняної та зарубіжної науково-технічної літератури, патентного пошуку та досвіду роботи підприємств, установ, провідних фірм у відповідній галузі виробництва, економіки або науки;

- обгрунтування основних проєктних рішень або напрямів досліджень;

- можливі галузі застосування результатів проєкту.

Основна частина магістерської роботи складається $з$ декількох розділів. Рекомендується така наближена структура основної частини.

Розділ 1 містить опис проблеми, вводить у саму проблему, описує стан дослідження проблеми. У першому розділі студент-випускник систематизує 


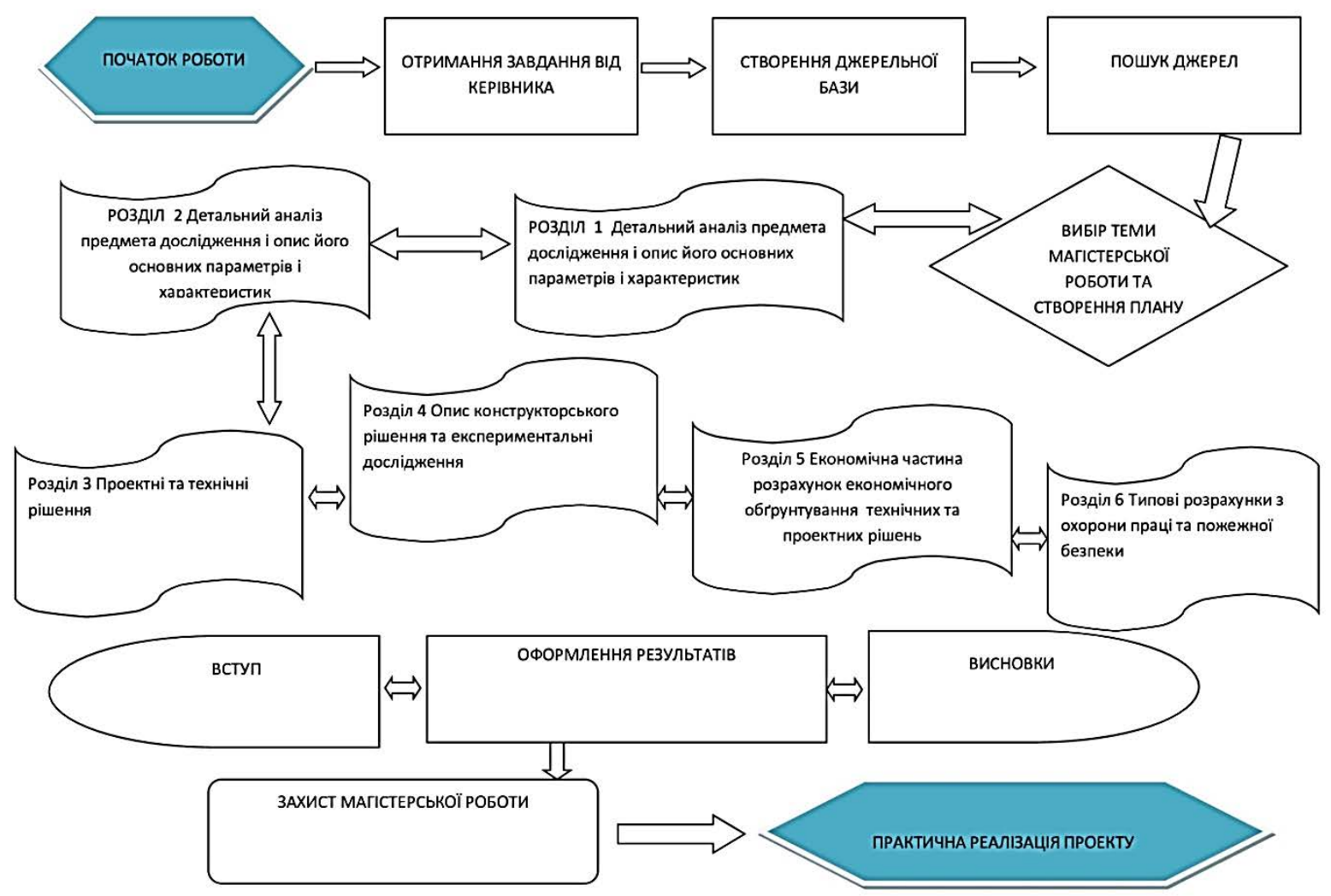

Рис. 1.

і аналізує, з огляду на тему роботи, наявні мережі, системи, машини і пристрої, комп’ютерні технології та програмні засоби. Необхідно висвітлити на основі вивчення наукової літератури, нормативних документів та інших матеріалів, рекомендованих науковим керівником або підібраних студентом самостійно, теоретичну суть і практичне значення предмета магістерської роботи; рівень опрацювання проблеми на момент його виконання. При цьому основну увагу слід приділити тим аспектам вирішення проблеми і підходам до ії вирішення, які передбачається розглянути в такій роботі. У цьому розділі потрібно продемонструвати набуті вміння щодо виконання технічної та проєктної виробничих функцій, наприклад: уміння виконувати постановку та формалізацію задач, уміння розробляти проєктне завдання тощо.

Розділ 2 містить детальний аналіз предмета дослідження і опис його основних параметрів і характеристик. У цьому розділі потрібно продемонструвати набуті вміння щодо виконання технічної та проєктної виробничих функцій, наприклад: уміння виконувати аналіз об’єктів, уміння формулювати критерії оцінки якості проєктних рішень тощо. Текст цього розділу слід ілюструвати схемами (наприклад, схема організаційної структури об'єкта і його апарату управління), таблицями, графіками, діаграмами, що показують динаміку розвитку об’ єкта.
Розділ 3 містить проєктні та технічні рішення. У цьому розділі потрібно продемонструвати набуті вміння щодо виконання технічної та проєктної виробничих функцій, наприклад: уміння розробляти формалізовані схеми або системи для опису математичних або імітаційних моделей технічного об'єкта відповідно до предмета магістерської роботи, виконувати необхідні математичні перетворення та розрахунки тощо. Необхідно продемонструвати набуті вміння щодо виконання технічної та проєктної виробничих функцій, наприклад: уміння розробляти структури та системи відповідно до предмета магістерської роботи, розробляти функціональні і принципові схеми, розробляти структури, алгоритми та тексти програм тощо.

Розділ 4 містить опис конструкторського рішення, що пропонується, та експериментальні дослідження. У цьому розділі потрібно продемонструвати набуті вміння щодо виконання конструкторської виробничої функції, наприклад: уміння розробляти документацію, необхідну для розробки та супроводу технічного об'єкта, та документацію, необхідну для розробки та супроводу ПО, тощо. Необхідно оформити результати експериментальних досліджень, розробку методики досліджень, опис експериментального обладнання, аналіз результатів експерименту. 


\section{КОМП'ЮТЕРНІ НАУКИ ТА ІНФОРМАЦІЙНІ ТЕХНОЛОГІЇ № Зロ 2020}

Розділ 5 - це економічна частина; у цьому розділі потрібно продемонструвати набуті вміння щодо виконання розрахунку економічного обгрунтування технічних та проєктних рішень із застосуванням програми Рroject Expert.

Розділ 6 містить типові розрахунки з охорони праці та пожежної безпеки. У цьому розділі установлюють вимоги, що визначають безпечне обслуговування виробу, зручності обслуговуючого персоналу, екологічну безпеку, що може виникнути під час експлуатації або утилізації виробу тощо. У процесі розробки завдання на ДРМ, у міру поглибленого розуміння майбутніх конструктивних і функціональних можливостей, виявляються параметри пристрою, шкідливі для людини і навколишнього середовища, і відповідно до наявних норм формулюються вимоги до розроблюваного пристрою. Перелік цих вимог узгоджується 3 консультантами 3 питань охорони праці.

У висновках до магістерської роботи студент повинен підбити підсумки вивчення теми, обгрунтовано викласти свої погляди з головних питань, розглянутих у роботі. Можуть бути вказані перспективи подальшої розробки теми та можливість впровадження або застосування результатів. Тут підсумовуються i аналізуються результати розробки, виходячи 3 технічних, економічних і соціальних аспектів. Висновки не повинні містити нових відомостей, фактів, аргументів і т.д., висновки повинні логічно витікати 3 основного тексту роботи.

Науково-дослідна робота студента вважається закінченою після успішного захисту.

\section{ВИСНОВКИ}

Таким чином, стратегічна карта - ефективний спосіб упорядкування студентської роботи з написання магістерських робіт. Підприємство розвивається більш ефективно, маючи стратегічну карту, яка враховує максимальну кількість факторів та фіксує очікувані результати. Науково-дослідницька робота студента також буде більш ефективною, якщо в процесі використовувати прийоми та методи стратегічного менеджменту у вигляді складання стратегічної карти магістерської роботи.

Стратегічна карта - простий та наочний спосіб відбиття стратегії студента, цілей та напрямів його пошукової діяльності. Головний плюс таких карт їх гнучкість. Процес розробки має об'єднувати всіх зацікавлених осіб: наукового керівника, викладачів кафедри, студента. Карти можуть мати різний вигляд. Для студентів напряму «Комп'ютерні науки» це причинно-наслідкові діаграми. Першим кроком студента під час написання магістерської роботи є саме складання такої діаграми. Вона має включати всі етапи пошукової роботи та очікувані результати.

\section{REFERENCES}

[1] Diachenko, O. (2013). Stratehichna karta yak instrument efektyvnoho upravlinnia finansovoiu stiikistiu pidpryiemstva [Strategic map as a tool for effective management of financial stability of the enterprise]. Teoretychni i praktychni aspekty ekonomiky ta intelektualnoi vlasnosti. Vol. 2, No 1. Retrieved from: http://tpa.pstu.edu/article/view/19027.

[2] Yepifanova, I. (2017). Stratehichni karty yak vazhlyvyi element innovatsiinoi stratehii [Strategic maps as an important element of innovation strategy]. Materialy XLVI naukovo-tekhnichnoi konferentsii pidrozdiliv VNTU, Vinnytsia. Retrieved from: https://conferences.vntu.edu.ua/index.php/all-fm/all-fm-2017/paper/view/1824.

[3] Tolpezhnikov, R., Pastoshchuk, O. (2013). Stratehichna karta pidpryiemstva yak osnova pidvyshchennia vartosti pidpryiemstva [Strategic map of the enterprise as a basis for increasing the value of the enterprise]. Ekonomichnyi analiz, Vol. 12(4), pp. 84-88. Retrieved from: http://nbuv.gov.ua/UJRN/ecan_2013_12\%284\%29_21.

[4] Bersutskyi, A., Kamenska, O. (2013). Stratehichna karta yak efektyvnyi instrument upravlinnia liudskym kapitalom [Strategic map as an effective tool for human capital management]. Teoretychni ta praktychni aspekty ekonomiky ta intelektualnoi vlasnosti. No 1, pp. 229-234.

[5] Solovii, Kh. (2013). Formuvannia stratehichnoi karty pidpryiemstva / Kh. Ia. Solovii, Z. I. Kozar [Formation of a strategic map of the enterprise]. III Mizhnarodna naukovo-praktychna konferentsiia "Problemy formuvannia ta realizatsii konkurentnoi polityky". Lviv: Natsionalnyi universytet "Lvivska politekhnika”, pp. 224-225. Retrieved from: http://ena.lp.edu.ua:8080/ bitstream/ntb/29007/1/134_224_225.pdf.

[6] Sablina, N., Kuzmenko, T. (2013). Formuvannia stratehichnykh kart u ramkakh realizatsii protsesu upravlinnia finansovoiu bezpekoiu pidpryiemstva [Formation of strategic maps in the implementation of the process of financial security management of the enterprise]. Biznesinform. No 4, pp. 326-331.

[7] Litvak, B. (2013). Strategicheskiy menedzhment: uchebnik dlya bakalavrov [Strategic management: a textbook for bachelors]. Moscow: Yurayt. Retrieved from: http://urss.ru/PDF/add_ru/171351-1.pdf [in Russian].

\section{СПИСОК ВИКОРИСТАНОЇ ЛІТЕРАТУРИ}

[1] Дяченко О. В. (2013) Стратегічна карта як інструмент ефективного управління фінансовою стійкістю підприємства. Теоретичні і практичні аспекти економіки та інтелектуальної власності. T. 2. № 1. URL: http://tpa.pstu.edu/article/ view/19027 (дата звернення: 03.09.2020).

[2] Спіфанова I. Ю. (2017) Стратегічні карти як важливий елемент інноваційної стратегії. Матеріали XLVI науковотехнічної конференції підрозділів ВНТУ, Вінниця, 22-24 березня 2017 p. URL: https://conferences.vntu.edu.ua/index. php/all-fm/all-fm-2017/paper/view/1824 (дата звернення: 05.09.2020). 
[3] Толпежніков Р. (2013) Стратегічна карта підприємства як основа підвищення вартості підприємства / Р. Толпежніков, О. Пастощук. Економічний аналіз. Т. 12(4). C. 84-88. URL: http://nbuv.gov.ua/UJRN/ecan_2013_12\%284\%29_21 (дата звернення: 01.09.2020).

[4] Берсуцький А. Я. (2013) Стратегічна карта як ефективний інструмент управління людським капіталом / А. Я. Берсуцький. О. О. Каменська. Теоретичні та практичні аспекти економіки та інтелектуальної власності. Т. 2. № 1. С. 229-234.

[5] Соловій Х. Я. (2013) Формування стратегічної карти підприємства / Х. Я. Соловій, 3. І. Козар. III Міжнародна науково-практична конференція «Проблеми формування та реалізачї конкурентної політики», (Львів, 2013 рік). Львів : Національний університет «Львівська політехніка». С. 224-225. URL: http://ena.lp.edu.ua:8080/bitstream/ ntb/29007/1/134_224_225.pdf (дата звернення: 04.09.2020).

[6] Сабліна Н. В. (2013) Формування стратегічних карт у рамках реалізації процесу управління фінансовою безпекою підприємства / Н. В. Сабліна, Т. Б. Кузьменко. Бізнесінформ. № 4. С. 326-331.

[7] Литвак Б .Г. (2013) Стратегический менеджмент : учебник для бакалавров Москва : Изд-во Юрайт. 507 с. URL: http://urss.ru/PDF/add_ru/171351-1.pdf (дата звернення: 01.09.2020).

(C) Ю. В. Деркаченко, Т. В. Бауліна, Т. В. Кухтик Дата надходження статті до редакції: 16.10 .2020 Дата затвердження статті до друку: 23.10.2020 